\title{
IDENTIFICATION OF CYCLOPROPYL FATTY ACIDS IN WALNUT (JUGLANS REGIA L.) OIL
}

\author{
Lumir Ondrej Hanus ${ }^{\mathrm{a} *}$, Paulina Goldshlag ${ }^{\mathrm{b}}$, Valery Mikhail Dembitsky ${ }^{\mathrm{a}}$
}

\author{
a Department of Medicinal Chemistry and Natural Products, School of Pharmacy, P.O. Box 12065, The Hebrew University \\ of Jerusalem, Jerusalem 91120, Israel \\ ${ }^{b}$ Laboratory of Mass Spectrometry, Ministry of Agriculture, P.O. Box 78, Beth Dagan 50250, Israel \\ e-mail:lumir@cc.huji.ac.il
}

Received: March 8, 2008; Accepted: April 15, 2008

Key words: GC-MS/Cyclopropyl acids/Walnut oil/Sunlight exposure

Aim: Identification of cyclopropyl fatty acids in walnut oil.

Method: GC/MS method was developed for the determination of eight cyclopropyl fatty acids in walnut (Juglans regia) oil.

Results: Monocyclopropane acids: methyl 9-cyclopropyl-nonanoate, 6,7-methylene-, 8,9-methylene-, 9,10-methylene-, 11,12-methylene octadecanoates, and dicyclic acid - methyl 9,10,12,13-dimethylene octadecanoate, tricyclic acid - methyl 9,10,12,13,15,16-trimethylene octadecanoate, and unsaturated - methyl 2-octylcyclopropene-1-octanoate were detected in walnut oil by GC-MS and their mass spectra studied. Four cyclic fatty acids were identified for the fist time in seed oils.

Conclusions: Eight cyclopropyl fatty acids were detected in the Mediterranean nuts for the first time.

\section{INTRODUCTION}

Cyclopropenoid fatty acids (CPFA) are found in at least two phylogenetically distant groups of plants belonging to families: Bombacaceae, Malvaceae, Sterculiaceae ${ }^{1-4}$, Leguminosae $^{5}$, and Rannunculaceae ${ }^{6}$. Most of the seed oils consist predominantly of triacylglycerols. Fatty acids in the plant kingdom are mainly saturated or olefinic unsaturated straight-chain $\mathrm{C}_{16}$ or $\mathrm{C}_{18}$ compounds with a terminal carboxyl group. In the diene and triene derivatives, respectively, the double bonds are interrupted by a methylene group. Typical members incorporating these structure types are palmitic, stearic, palmitoleic, oleic, linoleic, and linolenic acid. Although they are best known as components of seed oils, CPFA do occur in vegetative plant parts $^{6-10}$.

CPFA have been the subject of many investigations due to their carcinogenic ${ }^{11,12}$, cocarcinogenic ${ }^{13-15}$ and other biological, medical and mitogenic effects on animals ${ }^{16-18}$. The presence of CPFA in food is dangerous to human health ${ }^{19-23}$.

It is known that many chemical reactions such as oxidation, polymerization, hydrolysis, isomerization and cyclization occur during deep fat frying. ${ }^{19}$ These reactions lead to the formation of fatty acid geometrical isomers ${ }^{24}$, $\operatorname{dimers}^{25,26}$ CPFA $^{27-31}$ and polymeric triglycerides ${ }^{32-34}$ as well as some oxidative components ${ }^{24,35}$. It has been found that seed oils containing mono-, di- and tri- unsaturated fatty acids when heated to over $200{ }^{\circ} \mathrm{C}$ in the presence of air form a number of cyclic fatty acids, including CPFA $^{36-41}$.

This work is a continuation of our previous investigation of Mediterranean nut oils ${ }^{42}$ and presents new data about the CPFA formed from unsaturated fatty acids in nut oils rich particularly in linolenic and linoleic acids.

\section{EXPERIMENTAL}

\section{Samples}

Walnuts (Juglans regia) were purchased in a local market in Jerusalem in February 2005.

\section{Analytical procedure}

The walnuts $(500 \mathrm{~g})$ were shelled, and the kernels were homogenized in a high-speed unit. They were then spread as a layer $(0.2 \mathrm{~cm})$ in a special glass box with an open upper cover and exposed to sunlight for 100 days. After 30, 70 and 100 days, samples were used for GC/MS analysis. The lipids were extracted with a mixture of chloroformmethanol $(2: 1, \mathrm{v} / \mathrm{v})$, from control and three samples $(30$, 70 and 100 days) according to an established procedure ${ }^{43}$, followed by addition of a saturated solution of sodium chloride in water. The mixture was vigorously shaken for $30 \mathrm{~s}$. After phase separation the lower layer was removed, dried over sodium sulphate, and filtered. The oil residue was dissolved in $\mathrm{CH}_{2} \mathrm{Cl}_{2}$ and stored at $-20{ }^{\circ} \mathrm{C}$ prior to $\mathrm{GC} / \mathrm{MS}$ analysis.

GC/MS analysis of the methyl esters of fatty acids was performed on a Hewlett Packard 6890 series II chromatograph linked to a HP 5973 Mass detector equipped with HP automatic injector and a $30 \mathrm{~m}$ long, $0.25 \mathrm{~mm}$ ID, $0.25 \mu \mathrm{m}$ film thickness HP-5MS capillary column. The ionization energy was $70 \mathrm{eV}$. The carrier gas was He (flow $1.0 \mathrm{ml} / \mathrm{min}$ ). The temperature of the injection block was $250{ }^{\circ} \mathrm{C}$. The $\mathrm{GC}$ oven temperature was programmed as 
Table 1. Distribution of cyclopropyl fatty acids in walnut oil.

\begin{tabular}{|c|c|c|c|c|}
\hline Fatty acids (wt \% of total ME FAs) & Control & 30 days & 70 days & 100 days \\
\hline Total Saturated & 4.81 & 5.28 & 5.99 & 5.30 \\
\hline $16: 0$ & 3.62 & 3.79 & 4.04 & 3.63 \\
\hline $18: 0$ & 1.19 & 1.49 & 1.95 & 1.67 \\
\hline Total unsaturated & 92.85 & 88.03 & 83.18 & 76.01 \\
\hline$(Z)-9-18: 1$ & 21.34 & 18.86 & 15.88 & 13.25 \\
\hline$(\mathrm{Z}, \mathrm{Z})-9,12-18: 2$ & 65.40 & 64.21 & 63.96 & 60.51 \\
\hline$(Z, Z, Z)-9,12,15-18: 3$ & 6.11 & 4.96 & 3.34 & 2.25 \\
\hline Total CPFA & 0.16 & 1.73 & 2.96 & 5.57 \\
\hline 1. 9-cyclopropyl-nonanoate & n.d. & n.d. & 0.21 & 0.43 \\
\hline 2. 6,7-methylene octadecanoate & n.d. & 0.12 & 0.18 & 0.28 \\
\hline 3. 8,9-methylene octadecanoate & n.d. & 0.22 & 0.24 & 0.31 \\
\hline 4. 9,10-methylene octadecanoate & 0.16 & 0.97 & 1.18 & 2.29 \\
\hline 5. 2-octylcyclopropene-1-octanoate & n.d. & 0.11 & 0.45 & 0.67 \\
\hline 6. 11,12-methylene octadecanoate & n.d. & 0.31 & 0.42 & 0.62 \\
\hline 7. 9,10,12,13-dimethylene octadecanoate & n.d. & n.d. & 0.11 & 0.38 \\
\hline 8. 9,10,12,13,15,16-trimethylene octodecanoate & n.d. & n.d. & 0.17 & 0.59 \\
\hline Total dioic, keto, oxygenated, other & 2.18 & 4.96 & 7.87 & 13.12 \\
\hline
\end{tabular}

Structures CPFA refer to Fig. 1.

Abbreviations: n.d., not detected.

follows: initial temperature $60{ }^{\circ} \mathrm{C}(2 \mathrm{~min})$ followed by a temperature increase of $3{ }^{\circ} \mathrm{C} / \mathrm{min}$ up to $260{ }^{\circ} \mathrm{C}(10 \mathrm{~min})$ and second rate of $10^{\circ} \mathrm{C} / \mathrm{min}$ to the final temperature of $290{ }^{\circ} \mathrm{C}$ (10 min). Cyclopropyl FA were identified using Wiley $7^{\text {th }}$ Edition Library. Mass spectra and comparion with mass spectra published by other researchers.

\section{RESULTS AND DISCUSSION}

GC-MS analyses of all studied samples are presented in Table 1. Control samples contained only cyclopropane acid-9,10-methylene octadecanoate $(4,0.16 \%$ of total fatty acids). It was found that after sunlight exposure some other CPFA were produced (Fig. 1). During our experimental work, the air temperature in Jerusalem ranged from 36 to $46{ }^{\circ} \mathrm{C}$ (June - August, 2005). The concentration of CPFA increased during the experiment, and reached $5.57 \%$ of total fatty acids (Table 1). Many other oxygenated lipid compounds as well as cyclopropyl fatty acids were detected in walnut oil: dioic (dicarboxylic), keto, hydroxy, and epoxy fatty acids (not discussed in this paper). Their concentration was found up to $13 \%$. Mass spectra of the four cyclopropyl fatty acids are shown in Fig. 2.

Cyclopropane fatty acids, the most prevalent of the cyclic fatty acids, are widely distributed among both
Gram-positive and Gram-negative bacteria, including Brucellaceae, Clostridia, Enterobacteria, Lactobacilli, and Streptococci ${ }^{4}$,4 ${ }^{\text {, }}$ cis-11,12-Methyleneoctanoic (lactobacillic) acid 6, and cis-9,10-methylenehexadecanoic acid are the most commonly found cyclopropanoid acids in bacteria. An unusual fatty acid containing six cyclopropane rings was recently isolated from Streptomyces sp. ${ }^{45,46}$.

Previously, dihydrosterculic acid (4) as well as sterculic acid (5) were found in Pachira aquatica seed oils ${ }^{47}$. The biosynthesis of cyclopropane and cyclopropene fatty acids has been discussed in some reviews ${ }^{48,49}$.

CPFAs have also been found in the slime mold Polysphobdylium pallisum ${ }^{50}$, the freshwater amphipod Acanthogammarus grewingkii ${ }^{51}$, and in some marine invertebrates $^{52}$. CPFA has also been isolated from some pathogenic fungi ${ }^{53,54}$.

The chemistry of CPFA [55] including their mass spectra has been discussed in several papers ${ }^{56-58}$. Both in these publications and as well as from our own data, the characteristic peaks for monounsaturated methyl esters contain $m / z$ M-32 (loss of methanol from the ester function), $m / z$ M-74 (loss of the ester group plus one carbon from the chain) and $m / z$ M-116 (loss of the ester group plus four carbons from the chain) (see Fig. 2). Peaks which might be expected by fragmentation on either side of the cyclopropane rings at $m / z 113$ and 197 or 153 and 


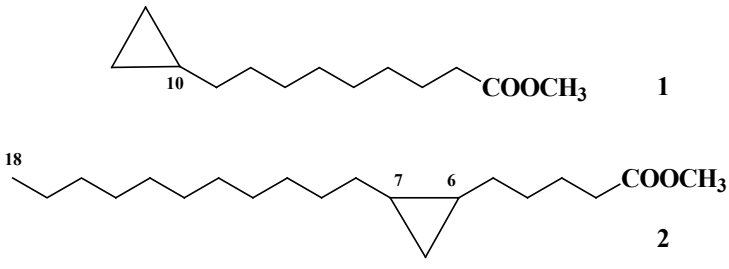<smiles>CCCCCCCCCC[C@@H]1C[C@H](CCCCCCCC(=O)OC)[C@@H]1C</smiles><smiles>CCCCCCCCC1C2C(CCCCCCCC(=O)OC)C12</smiles>

4<smiles>CCCCCCCCC1C2C(CCCCCCCC(=O)OC)C12</smiles>

5

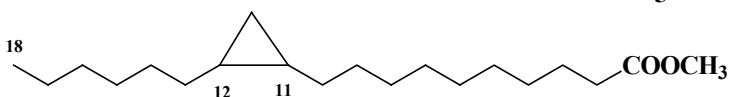

6

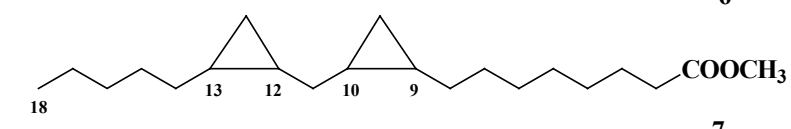

7

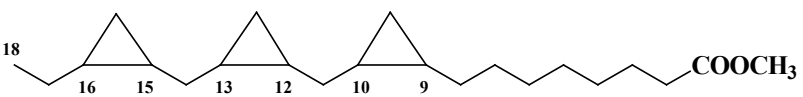

8

Fig. 1. Structural formulae of cyclopropyl fatty acids identified from walnut oil.

Names of the acids referred to in Table 1.

157 are more prominent in the mass spectrum of the cyclopropane fatty acid than in that of the parent ester.

GC/MS has been so far the method of choice for identifying the cyclopropane fatty acids in fats and oils formed during heating or similar treatment. However, the interpretation of the mass spectra is often difficult. According to ${ }^{30,36-41}$ the methyl ester of octadecanoic acids that contain cyclopropyl ring(s) give four characteristic fragments A, B, C and D, which are found in the mass spectra (see Fig. 2 and Fig. 3).

Electron impact mass spectrometry of methyl ester $\mathrm{C}_{18}$ fatty acids give fragments indicated in Fig. 3. Additional ion fragments are D-32 (loss of methanol and D-32-18 (further loss of water). A $(B+1)$ fragment is present in most spectra due to a protonation of fragment $B$. All these fragments are present in mass spectra of identified CPFA in the present work.

The results of this study show for the first time the presence of eight cyclopropyl fatty acids in the Mediterranean walnut. We do not know the origin of CPFA in walnut oil. However, it is possible that the CPFA originates from the intensively growing microflora promoted by sunlight exposure.

Other reasons why these compounds are present in walnuts oil include: the fact that CPFAs are formed from unsaturated fatty acids due to transformations such as oxidation and cyclization during heating fats and oils ${ }^{36-41}$.
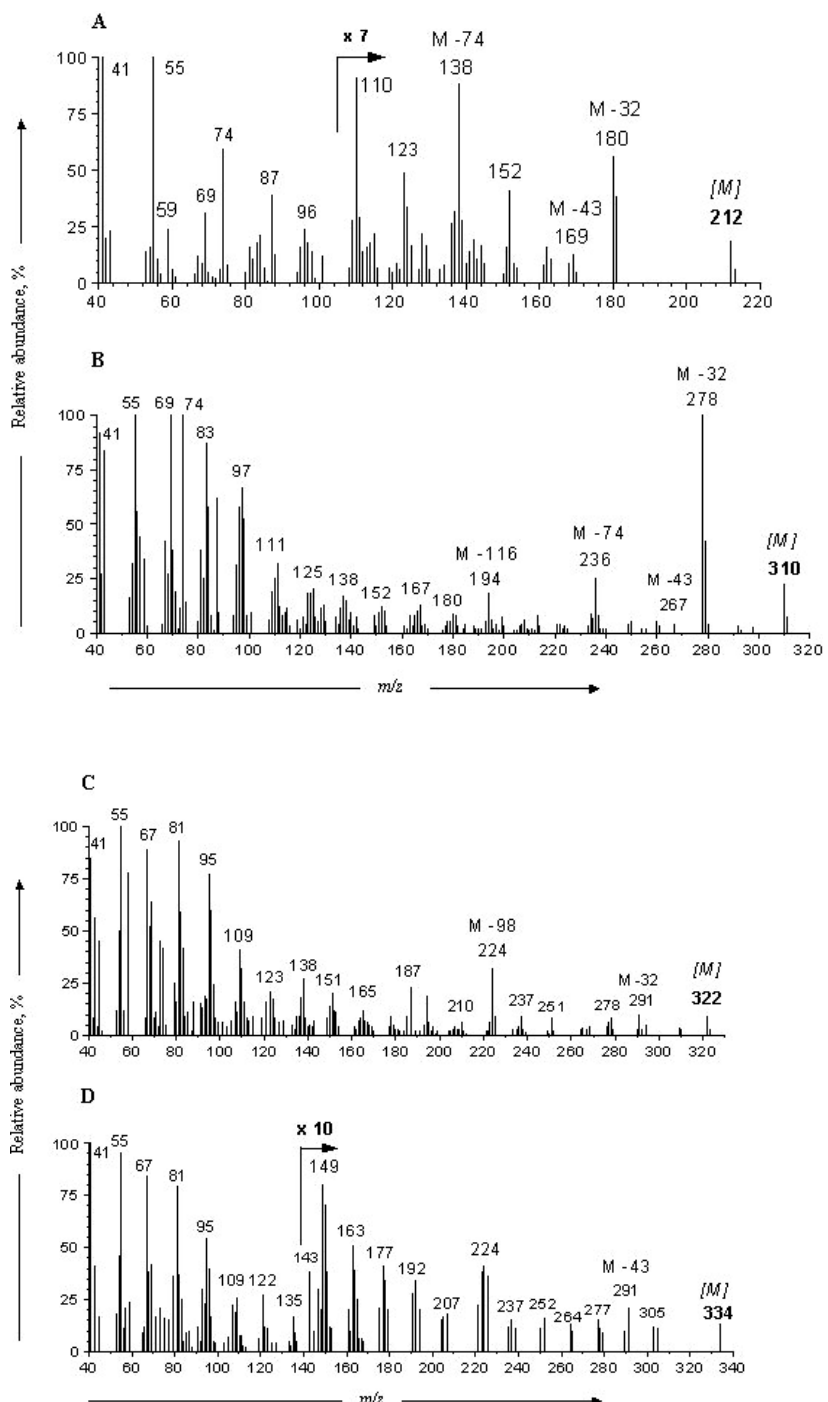

Fig. 2. Mass spectra of methyl esters of cyclopropyl fatty acids identified from walnut oil.

A. Cyclopropanenonanoic acid (1),

B. 2-Hexylcyclopropanedecanoic acid (6),

C. 2-[(2-pentylcyclopropyl)methyl]cyclopropane octanoic acid (7),

D. 2-[[2-ethylcyclopropyl)methyl]cyclopropyl]m ethyl]cycpropaneoctanoic acid (8).

Structures refer in Fig. 1.

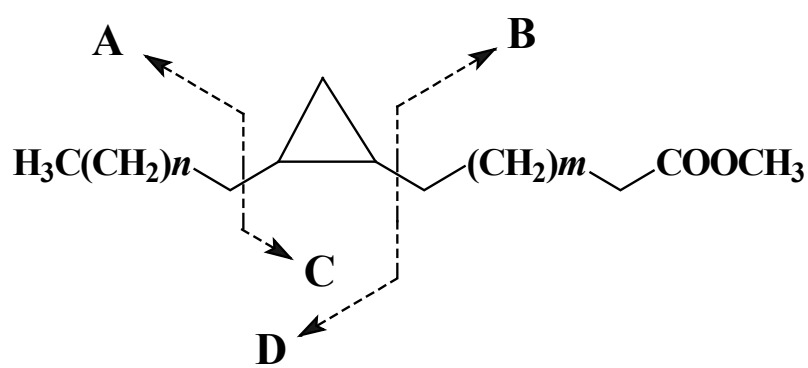

Fig. 3. Common EI mass spectral fragmentations of the cyclopropyl fatty acids. 
Another possibility is that these compounds represent metabolites that could be formed by the microflora found in walnuts. The microorganisms containing CPFA ${ }^{4,44,59}$ isolated from walnuts include: Pseudomonas flavescens sp. nov. ${ }^{60}$, Penicillium crustosum ${ }^{61}$, Aspergillus glaucus, $A$. niger, A. flavus, A. candidus, Penicillium cyclopium, $P$. viridicatum ${ }^{62}$, and $A$. parasiticus ${ }^{63,64}$. Isolates of the genera Alternaria, Cladosporium, Fusarium, and Helminthosporium have also been found in walnuts ${ }^{62}$. Humicola grisea var. themoidae and Thermoascus aurantiacus are rarely encountered in walnuts ${ }^{63,64}$. Those microorganisms living at $45{ }^{\circ} \mathrm{C}$ and over $^{63,64}$ may also produce and accumulate mycotoxins, $\mathrm{CPFA}^{53,54}$ and other metabolic products are degradation products formed by these microorganisms ${ }^{54}$. Which of these hypotheses is right, is difficult to say. In our opinion, it is the combination of the above hypotheses that can best explain the phenomenon.

\section{REFERENCES}

1. Schmid KM, Patterson GW. Distribution of cyclopropenoid fatty acids in malvaceous plant parts. Phytochemistry 1988; 27:28312834.

2. Mustafa J, Gupta A, Ahmad MS, Jr, Ahmad F, Osman SM. Cyclopropenoid fatty acids in Gnetum scandens and Sterculia pallens seed oils. J Am Oil Chem Soc 1986; 63:1191- 1192.

3. Bohannon MB, Kleiman R. Cyclopropene fatty acids of selected seed oils from Bombacaceae, Malvaceae, and Sterculiaceae. Lipids 1978; 13:270-273.

4. Christie WW. Topics in Lipid Chemistry, (Gustone, F.D., Ed), London, Logos, 1970; Vol. 1, pp. 1-49.

5. Daulatabad CD, Hosamani KM, Desai VA, Alawadi KR. Cyclopropenoid fatty acids in Leguminosae oils. J Am Oil Chem Soc 1998; 64:1423.

6. Aitzetmuller K, Vosmann K. Cyclopropenoic fatty acids in gymnosperms: The seed oil of Welwitschia. J Am Oil Chem Soc 1998; 75:1761-1765.

7. Spitzer V. Screening analysis of unknown seed oils. Fett-Lipid 1999; 101:2-19.

8. Lukina MY. Structure and reactivity of cyclopropane and its derivatives. Russ Chem Rev 1962; 31:419-439.

9. Vickery JR, Whitfield FB, Ford GL, Kennett BH. The fatty acid composition of Gymnospermae seed and leaf oils. J Am Oil Chem Soc 1984; 61:573-575.

10. Yano I, Nichols BW, Morris LJ, James AT. The distribution of cyclopropane and cyclopropene fatty acids in higher plants (Malvaceae). Lipids 1982; 7:30-34.

11. Hendricks JD, Sinnhuber RO, Loveland PM, Pawlowski NE, Nixon JE. Hepatocarcinogenicity of glandless cottonseeds and cottonseed oil to rainbow trout (Salmo gairdnerii). Science 1980; 208:309311.

12. Sinnhuber RO, Lee DJ, Wales JH, Landens MK, Keyl AC. Hepatic carcinogenesis of aflatoxin M1 in rainbow trout (Salmo gairdneri) and its enhancement by cyclopropene fatty acids. Cancer Res 1974; 53:1285-1291.

13. Sinnhuber RO, Lee DJ, Wales JH, Ayres JL. Dietary factors and hepatoma in rainbow trout (Salmo gairdneri). 2. Cocarcinogenesis by cyclopropenoid fatty acids and effect of gossypol and altered lipids on aflatoxin-induced liver cancer. J Natl Cancer Inst 1968; 41:1293-1299.

14. Lee DJ, Wales JH, Sinnhuber RO. Hepatoma and renal tubule adenoma in rats fed aflatoxin and cyclopropenoid fatty acids. $\mathbf{J}$ Natl Cancer Inst 1969; 43:1037-1044.

15. Lee DJ, Wales JH, Sinnhuber RO. Promotion of aflatoxin-induced hepatoma growth in trout by methyl malvalate and sterculate. Cancer Res 1971; 31:960-969.
16. Tumbelaka LI, Slayden OV, Stormshak F. (1994). Action of cyclopropenoid fatty acid on the Corpus luteum of pregnant and nonpregnant ewes. Biol Reprod 1994; 50:253-257.

17. Andrianaivo-Rafehivola A.A, Siess MH, Gaydou EM. Modifications of hepatic drug-metabolizing enzyme activities in rats fed baobab seed oil containing cyclopropenoid fatty acids. Food Chem Toxicol 1995; 33:377-382.

18. Matlock JP, Nixon JE, Pawlowski NE. Altered lipid metabolism and impaired clearance of plasma cholesterol in mice fed cyclopropenoid fatty acids. Toxicol Appl Pharmacol 1985; 80:457-466.

19. Artman NR. The chemical and biological properties of heated and oxidized fats. Adv Lipid Res 1969; 7:245-330.

20. Nolen GA, Alexander JC, Artman NR. (1967). Long-term rat feeding study with used frying fats. J Nutr 1967; 93:337-349.

21. Crampton EW, Common RH, Farmer FA, Florence A., Wells AF, Crawford D. Studies to determine the nature of the damage to the nutritive value of some vegetable oils from heat treatment. III. The segregation of toxic and nontoxic material from the esters of heat-polymerized linseed oil by distillation and by urea adduct formation. J Nutr 1953; 49:333-346.

22. Potteau B, Lhuissier M, Leclerc J, Custot F, Mezonnet R, Cluzan R. . Composition and physiological effects of heated soyabean oil and of its various fractions. I. Chemical Study. Rev Fr Corps Gras 1970; 17:143-153.

23. Potteau B, Lhuissier M, Leclerc J, Custot F, Mezonnet R, Cluzan R. Composition and physiological effects of heated soybean oil and of the various fractions obtained from this oil. 2. Physiological study. Rev Fr Corps Gras 1970; 17:235-245.

24. Grandgirard A, Sebedio JL, Fleury J. Geometrical isomerization of linolenic acid during heat treatment of vegetable oils. J Am Oil Chem Soc 1984; 67:1563-1569.

25. Ottaviani P, Graille J, Perfetti P, Naudet M. Products of thermal and oxidative reactions of heated oil. 2. Nonpolar or slightly polar compounds. Chem Phys Lipids 1979; 24:57-77.

26. Perkins EG, Wantland LR. Characterization of nonvolatile compounds formed during thermal oxidation of 1-linoleyl-2,3 distearin. 3. Evidence for presence of dimeric fatty acids. J Am Oil Chem Soc 1973; 50:459-461.

27. Frankel EN, Smith LM, Hamblin CL, Crevelinand RK, Clifford AJ. Occurrence of cyclic fatty acid monomers in frying oils used for fast foods. J Am Oil Chem Soc 1984; 61:87-94.

28. Grandgirard A, Julliard F. Determination of cyclic monomers in heated oils - a critical study. Rev Fr Corps Gras 1983; 30:123149.

29. Gere A, Sebedio JL, Grandgirard A. Studies on some hungarian fats and oils obtained from commercial frying processes. Fette Seifen Anstrichm 1985; 87:359-362.

30. Potteau B, Dubois P, Rigaud J. GLC - MS characterization of C18 - saturated cyclic acids prepared from either thermally polymerized or thermally oxidized linseed oils. Ann Technol Agric 1978; 27:655-679.

31. Gente M, Guillaumin R. Cyclic monomers evaluation in vegetable oils. Rev Fr Corps Gras 1977; 24:211-218.

32. Perkins EG, Taubold R, Hsieh A. Gel-permeation chromatography of heated fats. J Am Oil Chem Soc 1973; 50:223-225.

33. Schulte, E. Determination of polymerized triglycerides by gel chromatography. Fette, Seifen, Anstrichm 1982; 84, 178-180.

34. Aitzetmuller K. Recent progress in the high-performance liquid chromatography of lipids. Prog Lipid Res 1983; 21:171-193.

35. Naudet M. Study of heated oils. 3. Chemical constitution of thermo-oxidative alteration products. Rev Fr Corps Gras 1977; 24:489492.

36. Sébédio JL, Gnaedig S, Chardigny JM. Recent advances in conjugated linoleic acid research. Curr Opin Clin Nutr Metab Care 1999; 2:499-506.

37. Dobson G, Christie WW, Sebedio JL. Saturated bicyclic fatty acids formed in heated sunflower oils. Chem Phys Lipids 1997; 87:137147.

38. Chardigny JM, Sébédio JL, Grandgirard A, Martine L, Berdeaux O, Vatčle J. Identification of novel trans isomers of 20:5n-3 in liver lipids of rats fed a heated oil. Lipids 1996; 31:165-168. 
39. Sebedio JL, Catte M, Boudier MA, Prevost J, Grandgirard A Formation of fatty acid geometrical isomers and of cyclic fatty acid monomers during the finish frying of frozen prefried potatoes. Food Res Internat 1996; 29:109-116.

40. Dobson G, Christie WW, Sebedio JL. Monocyclic saturated fatty acids formed from oleic acid in heated sunflower oils. Chem Phys Lipids 1996; 82:101-110.

41. Sebedio JL, Grandgirard A. Cyclic fatty-acids - natural sources, formation during heat-treatment, synthesis and biological properties. Prog Lipid Res 1989; 28:303-336.

42. Dembitsky VM, Goldshlag P, Srebnik M. Occurrence of dicarboxylic (dioic) acids in some Mediterranean nuts. Food Chem 2002; 76:469-473.

43. Christie WW. Gas Chromatography and Lipids. A Practical Guide. The Oil Press, Ayr. 1989.

44. Goldfine H. Comparative aspects of bacterial lipids. Adv Microbiol Physiol 1972; 8:1-58

45. Kuo MS, Zienlinski RJ, Cialdella JI, Marschke CK, Dupuis MJ, Li GP, Koosterman DA, Spilman CH, Marshall VP. Discovery, isolation, structure elucidation, and biosynthesis of U-106305, a cholesteryl ester transfer protein inhibitor from UC-11136. J Am Chem Soc 1995; 117:10629-10635.

46. Barrett AG, Hamprecht D, White AJP, Williams DJ. Total synthesis and stereochemical assignment of the quinque-cyclopropane containing cholesteryl ester transfer protein inhibitor U-106305. J Am Chem Soc 1996; 118:7863-7869.

47. Spitzer V. GC-MS characterization (chemical ionization and electron impact modes) of the methyl esters and oxazoline derivatives of cyclopropenoid fatty acids. J Am Chem Soc 1991; 68:963-969.

48. Moore BS, Floss HG. in Comprehensive Natural Products Chemistry, Barton, D., Nakanishi, K. and Meth-Cohn, O., Eds, Elsevier, Amsterdam, 1999; Vol. 1, pp. 61-82.

49. Mangold HK, Spener F. Biosynthesis of cyclic fatty acids. In Biochemistry of Plants, Stumpf, H. Ed., Acad. Press, New York, 1980; Vol. 4, pp. 647-663.

50. Saito T, Ochiai H. Fatty acid composition of the cellular slime mold Polysphondylium pallidum. Lipids 1998; 33:327-332.
51. Rezanka T, Dembitsky VM. Identification of unusual cyclopropane monounsaturated fatty acids from the deep water lake invertebrate Acanthogammarus grewingkii. Comp Biochem Physiol 1994; 109B:407-413.

52. Gerwick WH, Nagle DG, Proteau PJ. Oxylipins from marine invertebrates. Topics Curr Chem 1993; 167:117-180.

53. Jackson LL, Frear DS. Lipids of rust fungi. I. Lipid metabolism of germinating flax rust uredospores. Can J Biochem 1967; 45:13091315 .

54. Abbott BJ, Gledhill WE. The extracellular accumulation of metabolic products by hydrocarbon-degrading microorganisms. Adv Appl Microbiol 1971; 14:249-388.

55. Lie Ken Jie MSF. in Handbook of Chromatography: Lipids, Mangold, H.K., Ed., CRC Press, 1984; Vol. 1, pp. 277-294.

56. Christie WW, Holman RT. Mass spectrometry of lipids .I. Cyclopropane fatty acid esters. Lipids 1966; 1:176-182.

57. Murphy RC. Mass Spectrometry of Lipids (Handbook of Lipid Research), New York, Plenum Press, 1993; Vol. 7, 71-130.

58. McCloskey JA. Topics in Lipid Chemistry. Gunstone F.D., Ed., London, Logos Press, Ltd., 1971; Vol. 1, 369-440.

59. Ratledge C, Wilkinson SG. Eds., Microbial Lipids. Acad. Press, London, 1988; Vols. 1 \& 2.

60. Hildebrand DC, Palleroni NJ, Hendson M, Toth J, Johnson JL. Pseudomonas flavescens sp. nov, isolated from walnut blight cankers. Int J Syst Bacteriol 1994; 44:410-415.

61. Richard JL, Bacchetti P, Arp LH. Moldy walnut toxicosis in a dog, caused by the mycotoxin, penitrem-A. Mycopathologia 1981; 76:5558.

62. Mislivec PB, Bruce VR, Andrews WH. Mycological survey of selected health foods. Appl Environ Microbiol 1979; 37:567-571.

63. Abdel-Gawad KM, Zohri AA. Fungal flora and mycotoxins of 6 kinds of nut seeds for human consumption in Saudi Arabia. Mycopathologia 1993; 124:55-64.

64. Abdel-Hafez AI, Saber SM. Mycoflora and mycotoxin of hazelnut (Corylus avellana L) and walnut (Juglans regia L) seeds in Egypt. Zentralbl Mikrobiol 1993; 148:137-147. 